\title{
Moral Luck in the Films of Woody Allen
}

\author{
By Ewa Mazierska
}

Fall 2011 Issue of KINEMA

MORAL LUCK IN THE FILMS OF WOODY ALLEN

\author{
We happened to have won the war. But if we didn't win the war, then history would be created \\ differently. \\ (Judah's aunt in Crimes and Misdemeanors)
}

The purpose of this essay is to discuss how moral issues are represented in two films of Woody Allen: Crimes and Misdemeanors (1989) and Match Point (2005). My principal tool of analysis is the concept of 'moral luck', elaborated in an essay of the same title by Bernard Williams (1929-2003) (see Williams 1981a), widely cited as the most important British moral philosopher of his time. I am using this concept because these two Allen films can serve as a perfect illustration of its validity or, conversely, because the idea of moral luck supports the way the director deploys moral problems in his films.

My discussion will consist of three parts. In the first I will summarise Williams' concept of moral luck. In the second I will apply it to the situations represented in Crimes and Misdemeanors and Match Point. Finally, I will attempt to contextualise Allen's ethics, linking it to the ideology dominating in the West.

\section{The concept of moral luck}

In arguably his most influential essay, 'Moral luck', Bernard Williams presents his views on the character of morality by contrasting them to Kantianism and, in a smaller measure, to Utilitarianism. Hence, in order to understand Williams' concepts, we should begin by reconstructing his views on these two doctrines. For Kant, moral value lies in the intention, not in the result of a specific action and it is immune from luck. Williams writes about Kant's ethics, 'Anything which is the product of happy or unhappy contingency is no proper object of moral assessment and no proper determinant of it, either... The successful moral life, removed from considerations of birth, lucky upbringing, or indeed of incomprehensible Grace of nonPelagian God, is presented as a career open not merely to the talents, but to a talent which all rational beings necessarily possess in the same degree' (Williams 1981a: 21). Kant attaches to moral value special dignity and importance - it is a supreme value. It creates the Highest Good, making individuals happy. In fact, in 'Kant's universe' happiness is in proportion to morality' (see Kant 2004: 132-3).

Accepting these premises leads to a view of the world, in which every person is in the same distance to any moral deed and all deeds can be assessed using the same measure, so to speak, unconditioned by history or culture. Kant's moral philosophy, despite its reputation as being severe, even repulsive, in Williams' opinion has a significant attraction as it offers solace to a sense of the world's unfairness (ibid.: 21), similarly to Christian religions that promote a vision of the world in which all people as moral subjects are equal. Conversely, Kantianism can be viewed as insensitive or even cruel by putting the same moral obligations on those who are in very difficult circumstances to fulfil them and the rest of the population. For example, it ignores the fact that people deprived of the means to fulfil their most basic needs find it more difficult to preserve basic decency than those in comfortable social and economic positions.

According to Utilitarianism, moral intentions matter only as far as they lead to morally satisfactory consequences because the moral worth of an action depends solely on its contribution to overall utility. Hence, the advocate of this position will encourage an agent to commit a morally distasteful act if it leads to greater utility than refraining from this act (see Williams 1981b: 40-53). Moreover, Utilitarianism 'strikingly abstracts from the separateness of agents' (Williams 1981c: 3). 'The basic bearer of value for Utilitarianism is the state of affairs' (ibid.: 4), as opposed to an individual.

Contrary to Kant, Williams argues that when judging human actions the consequences of human actions should be taken into account. Secondly, luck plays a major role in morality. Thirdly, moral values are not supreme over other values. Fourthly, moral sentiments cannot be modelled on a view of the world in which every happening and every person is at the same distance. The last two statements divide Williams not only from Kant, but also from Utilitarianism, which edifies 'utility' over any other value and tends to disregard 
the sentiments of a small number of individuals who pay a moral price for some greater utility. Williams, by contrast, claims that 'The idea that there has been a moral cost itself implies that something bad has been done, and, very often, that someone has been wronged, and if the people who have been wronged do not accept the justification, then no-one can demand that they should. It is for them to decide how far they are prepared to adopt the perspective within which the justification counts' (Williams 1981a: 37). To put it differently, for Williams there is no absolute vantage point from which human acts can be objectively and precisely assessed.

The author does not define luck, but he distinguishes different types of luck: incident luck and constitutive luck. The first refers to the set of external circumstances, the second - to 'incidents' of birth, such as coming from a particular family or class or having a particular character. Williams supports different elements of his concept by referring to a number of real and hypothetical characters and situations. Among them is that of 'Gauguin', whom he defines as a creative artist who turns away from human claims on him in order to live a life in which, as he supposes, he can pursue his art. Although Williams' 'Gauguin' withdraws from social life, he remains concerned about the moral obligations he neglects.

Thus, he is putting a great deal on a possibility which has not unequivocally declared itself early on. In such a situation the only thing that will justify his choice will be success itself. The justification, if there is to be one, will essentially be retrospective. The philosopher argues that if the famous painter would follow moral principles, he would not produce the excellent pictures which we now admire. However, his success does not absolve him from any guilt towards those who suffered through his pursuit of his goals. 'Even if he succeeds, he will not acquire a right that they accept what he has to say; if he fails, he will not even have anything to say' (ibid: $23-4$ ).

The case of 'Gauguin' leads Williams to the conclusion that 'While we are sometimes guided by the notion that it would be the best of worlds in which morality were universally respected and all men were of disposition to affirm it, we have in fact deep and persistent reasons to be grateful that that is not the world we have' (Ibid: 23). Another example used by Williams is that of Anna Karenina. Karenina remains conscious in her life with Vronsky of the cost exacted from others, above all from her son. She might have lived with the consequences, if things had gone better. However, they did not, therefore she commits suicide. 'Gauguin's' success and Anna Karenina's failure are thus largely a matter of luck (ibid.: 37-8). Accordingly, Williams argues that sentiments such as regret and satisfaction play a crucial role in our assessment of the moral dimensions of human deeds and their agents. Moreover, some moral dilemmas have no solutions that would satisfy everyone concerned. For example, the mother who can only save one child of two or sentence both of her offspring to perish, as shown in William Styron's novel, Sophie's Choice, cannot emerge morally pure from this situation.

On the whole, as Martha Nussbaum argues, Williams 'rejected Utilitarianism and Kantianism because both had simplified the moral life in ways that he found egregious, failing to understand, or even actively denying, the heterogeneity of values, the sometimes tragic collisions between one thing we care for and another. They also underestimated the importance of personal attachments and projects in the ethical life and, in a related way, neglected the valuable role emotions play in good choice. Finally, they failed to come to grips with the many ways in which sheer luck affects not only happiness but the ethical life itself, shaping our very possibilities for choice' (Nussbaum 2003).

Being a philosopher of morality, as perceived by Williams, requires subtlety and imagination. These qualities these days are more often associated with working in literature or cinema than in philosophy. Williams himself became known for his attempt to reorient the study of moral philosophy to the study of history, culture, politics and psychology, hence being anti-theory. ${ }^{(1)}$ It could be suggested that his scepticism of (grand) moral theories and his attention to detail bring him close to postmodernism, a paradigm with which Woody Allen is also connected. Accordingly, I will argue that by trying to marry Williams' concept of 'moral luck' with Allen's cinema I will act in the spirit of Williams' philosophy.

Williams' analysis of human behaviour in relation to morality can help his readers to make moral choices. For example, his discussion of moral consequences involved in political decisions might put off some people from entering politics or make them better understand why they keep distance from this sphere of social life. However, in his work we do not find any hierarchy of moral or, indeed, any values and, consequently, any 
specific answers to the question how to live, be moral or achieve happiness. ${ }^{(2)}$ To put it differently, his work has no ambition to compete with the Bible or any 'life manual'; it is more a tool to read the Bible or, for that matter, an Allen film.

\section{Moral luck in Crimes and Misdemeanors and Match Point}

Before I move on to analysing Allen's work, it is worth referring briefly to the question of interpretation of moral content of a feature film. It is safe to assume that this content is deployed chiefly by characters and plots, although other means also can be used to support certain moral positions, such as cinematography, editing or even music. Consequently, the obvious way to begin 'decoding' this content is by identifying moral positions (judgements, opinions and values) appropriated by the film's characters and their relations with each other. It might be and usually is an interesting and valuable task in itself, contributing to the development of both film and moral studies. In fact, a number of filmmakers identified with postmodern cinema, such as Atom Egoyan and Todd Solondz, suggest that 'ethical interpretation' of their films should finish here, namely in identifying the moral positions of the characters, because their objective is to illuminate moral conflicts, for which they see no satisfactory solutions, rather than moralistically promoting certain views or values.

However, the natural impulse of the film critic interested in moral issues is to go beyond this level of interpretation, and in the web of discourses emerging from the cinematic text try to discover one which can be assigned to the film's author, understood either as Barthes' 'scriptor' or even as a concrete, real individual who on and off screen has specific moral views. I am not against this practice and will myself use it in this essay, but I will do it with awareness that it is based on questionable assumptions. One such assumption is a correspondence between the moral values advocated by the text and those of its author. Such correspondence does not always need to exist, because films are not driven exclusively by the moral positions of their authors but also, for example, by their desire to entertain, flatter and provoke the viewers, or a wish to conduct an ethical experiment by identifying with a morally repulsive character. ${ }^{(3)}$ It might be a distinct possibility that Allen's films are such ethical experiments or provocations which aim at confronting viewers with their secret (im)moral thoughts. However, in this essay I am taking Allen's films at 'face value', so to speak, assuming, rightly or wrongly, that the film's moral discourse is also the discourse of Allen himself. On the basis of my specific interpretation of a film I will try to create a 'moral profile' of the real Woody Allen.

Crimes and Misdemeanors and Match Point are among the most serious and disquieting works in the large portfolio of Allen films and in this sense are regarded as unusual for this leading jester of contemporary American cinema. The first film in particular took critics by surprise. They saw in it a contemporary reading of themes elaborated by Dostoevsky, Strindberg and Bergman, as suggested by the very title which is reminiscent of Strindberg's Crime and Crime, Bergman's Crimes and Whispers and Dostoevsky's Crime and Punishment (see Geist 1989; Combs 1990). Surprise was sometimes combined with satisfaction, as reflected in such an opinion: 'The intrusion of brutal reality in Crimes and Misdemeanors takes Allen's work to a strikingly new level' (Strick 1990: 221). On other occasions, critics noted that Allen, being a natural comic, did not reach the level of complexity or tragedy, found in the works of Dostoevsky or his beloved Bergman (see Allen 1990; Combs 1990). In due course Crimes and Misdemeanors also became one of the most analysed films of this director. For example, the collection of essays entitled Woody Allen and Philosophy is largely devoted to this film (see Jarvie 2004; Lawler 2004; Pappas 2004).

The seriousness of Crimes and Misdemeanors and Match Point is conveyed by their very stories, which include premeditating and committing murders and, perhaps more significantly, the mode of narrating them. Unlike the bulk of Allen's films that distance the viewer from the narrative and create the impression that what he is watching is not life itself, but its representation and interpretation, these two films draw the viewer's attention to the story itself. The distancing techniques, such as intertextual references and digressions, humour and fantasy, are used more sparingly and they serve to illuminate the moral questions conveyed by the stories, rather than taking us to a different reality.

Both films deal with a number of issues, such as the relationship between moral and other values, the effect of external and internal circumstances ('luck') on human behaviour and the way society should be organised to minimise the harm people inflict on each other when pursuing their selfish desires and needs. Allen, 
like Williams, offers complex answers to these questions, allowing different arguments to be presented and discussed. However, it is worth adding that his moral discourse, although polyphonic, is at the same time somehow limited because it is transmitted by the stories of male characters who test their moral qualities in relations with women. Moreover, Allen also casts men in the role of moral authorities of these men. Such positioning of men and women is meaningful, as it conveys the traditional, misogynist idea that men are moral agents, whilst women are purely the objects of their actions without agency of their own.

Crimes and Misdemeanors consists of two stories, whose main protagonists are Judah, an affluent and respected late-middle aged ophthalmologist and Cliff, a rather unsuccessful documentary filmmaker. These stories run in parallel and only meet at the end, at a wedding which both characters attend. Judah's story comes across as more serious; the eponymous crimes are committed in his part. During the course of the action it turns out that his image as a perfect family man and pillar of the community is only a façade behind which a less appealing truth lies. Judah has a mistress, Dolores and in the past committed some financial offences which she helped him to cover up. Moreover, when Dolores, who wants Judah to leave his family, threatens to expose his affair and his past embezzlements to his wife, he orders his gangster brother to mastermind her murder.

The main feature of Cliff's sad predicament is his successful brother-in-law, Lester. Both Cliff and Lester make films, but whilst Cliff represents the serious, non-mainstream end of the media, making documentaries, exhibited at some obscure film festivals, Lester produces popular sitcoms and soap operas. Cliff has no luck with women and even his own wife holds him in contempt. Lester, by contrast, is adored by women and has plenty of affairs. Cliff's unhappiness reaches its lowest point when he falls in love with Halley, a modest and serious woman who works as an associate producer in Lester's team. Although he and Halley seem to have much in common, such as love of old films, and initially she shows sympathy to the hapless documentarist, in the end she abandons him and marries Lester, breaking Cliff's heart.

Both Judah and Cliff's stories and discourses built around them illustrate the points Williams made in his theory of 'moral luck'. Firstly, for Judah moral values are not superior over other values. On the contrary, they become almost meaningless when his material comfort and social position are at stake. As he himself puts it, he will not allow Dolores to ruin his life. He decides to get rid of his lover, despite the advice of a man who is a moral authority for him, Rabbi Ben, to confess his infidelity to his wife, hoping for forgiveness and understanding.

Secondly, Judah's problems derive from luck, as it is by accident that he meets Dolores, and his plan to get rid of his problems, resulting from this meeting, is also based on luck. He gambles that his crime of organising the murder of Dolores would be not detected. If it was detected, his regret would be much greater, encompassing not only his remorse that he killed his lover, but also that he ruined the future of his whole family, including his wife's and his brother. However, Judah goes unpunished, allowing him to alleviate his initial pangs of conscience, and assuring him that by disposing of Dolores he ultimately did the right thing. His very sin, in his opinion, diminished because society and God (if he exists) allowed him to get off the hook. Judah learnt that 'the most awful things can be done and lived with' (Combs 1990: 207).

Judah's story thus confirms Williams' point, that human deeds need to be judged retrospectively and there is a close relation between the visibility of crime and its gravity. Crimes that are unexposed and in due course forgotten are smaller than those that are placed in the public domain and recreated in numerous memories and reports. Visually the idea that the visibility of the crime matters is conveyed by the motif of eyes. As numerous critics observed, eyes feature prominently in the narrative of Crimes and Misdemeanours (see Fründt 1990; Girgus 2002; Lawler 2004). They are topics of many conversations, the camera often focuses on them and Judah himself is an ophthalmologist. In the film's opening scene of a jubilee dinner he tells his guests that his religious father warned him that God's eyes see everything and it might be the reason why he became an eye doctor. In the most shocking scene of the film, after being informed that Dolores is dead, Judah visits her apartment and finds her with eyes wide open.

Critics argue that Allen uses the motif of eyes as a metaphor of moral understanding and moral blindness. Apparently Judah can (physically) see perfectly but is morally blind, while Rabbi Ben is losing his physical sight but preserves his moral insight. Judah, in my opinion, is not morally blind but, as it was already stated, he cares about morality less than about his well-being and attempts to tailor his moral views in such a way 
that they justify his actions. The words of his father that God's eyes see everything do not threaten him because he does not believe in God any more, or at least he is untroubled about life beyond 'this' life. He suppressed his cultural Jewish heritage so that it only returns to him in memories or dreams, rather than affecting his decisions. Rabbi Ben, on the other hand, in his edification of moral values, becomes insensitive to other values that govern human behaviour and, consequently, cannot differentiate between the good man and the sinner. His blindness is thus a metaphor of his too narrow, therefore false outlook on life.

Judah's belief that if eyes are 'removed' from the scene of crime, if it remains in obscurity, in time it will diminish and be extinguished, points to the importance of the justice system as a chief guarantor of humans behaving morally. This idea has its place in philosophy. Most importantly, it was considered by Plato who raised the question of the possibility of a life outside the ethical order and, again, by Nietzsche and Williams (see 1985b). Williams believes that as long as man lives in a society, he is sentenced to entering into moral relations.

Although Judah is ultimately convinced that he did the right thing, both from moral and selfish perspective, he cannot deny that his actions involved a certain moral cost - Dolores' lost hopes for a happy life with him and, ultimately, her life. Her recurrent image in his memories is a testimony to that cost and Judah's debt towards her, confirming Williams' opinion that different people are at different distance towards the deeds which bear moral consequences.

The question that arises is whether Allen accepts Judah's justifications, whether he identifies with his discourse. I am unable to give a categorical answer to this question, but will suggest that taking into account the gravity of Judah's acts, the director presents his character with as much empathy and sympathy as possible. We always feel close to Judah, accessing his most intimate thoughts and feelings thanks to including his real and imaginary conversations with his friends, such as Ben, and members of his Jewish family. Moreover, he is often represented in close-up, his anguish perfectly visible to the viewer. In addition, Judah comes across as a social and popular man, always surrounded by his family and friends who adore him and cannot imagine their lives without him. Although this image is inconsistent with our knowledge of Judah as an adulterer and embezzler, it does not appear entirely false either, because the emotions he awakens in his family and friends are genuine. On the whole, he comes across as a relatively decent man who made mistakes and, at some point of his life, was unlucky, rather than an evil man.

In comparison with Judah, his victim, Dolores, is represented much less sympathetically. Typically we see her from a distance and through the eyes of her lover who would like to get rid of her. She also features in the memories of Judah as a nagging and needy woman with no friends, no children and no life of her own. Unlike Judah's wife and his daughter who come across as warm and feminine, Dolores resembles a witch: tall, dark and physically dominating her lover. She lives in a small and claustrophobic apartment, where she is herself suffocated and suffocates Judah.

The actress, who plays Dolores, Angelica Huston, specialises in the roles of strong, 'castrating', witch-like women. Shortly after completing Crimes and Misdemeanors, Huston played in Nicholas Roeg's Witches (1990), where she was depicted as a witch and children-hater, and it is difficult not to link these two roles. Dolores' position within the narrative and her demeanour also brings associations with the character played by Glenn Close in Fatal Attraction (1987) by Adrian Lyne (see Strick 1990: 221). Both women are represented as a threat to a healthy family who must be destroyed before they destroy these families. On the whole, one gets the impression that Dolores' life, although not meaningless, has a lesser value than that of Judah.

It is also worth emphasising that by letting Judah off the hook, Allen contravenes a Hollywood convention that crimes are punished. This convention plays, of course, a moral function: it is meant to discourage viewers from committing crimes. Accordingly, it can be argued that by not punishing his character, Allen shows him understanding and forgiveness. As previously mentioned, this reasoning is also adopted by Judah who from the fact that the police did not catch him derives that he is forgiven, by God, society or both.

Judah's self- exoneration is also partly supported by other arguments and discourses in the film. One such argument is presented by Judah's aunt in an imaginary scene of her disagreement with Judah's religious father. The aunt says 'We happened to have won the war. But if we didn't win the war, then history would be created differently? We can add that not only political history, but also the history of morality and 
morality itself might be different. If Hitler won the war, his moral guilt, if not entirely obliterated, would be much less than that ascribed to him after the war. The deaths of millions of people in concentration camps would be treated as at best 'collateral damage' rather than 'crimes against humanity'. Apparently Hitler himself followed this line of thinking when embarking on his programme of annihilating the Jews by taking inspiration from the pogroms of Armenians by Turks, in which five million people died. He claimed that nobody remembers or mourns the dead Armenians, because they lost, so nobody would remember ethnically cleansed Jews. The socially accepted definition of 'moral behaviour' might also have changed if the Nazis had won the war; certain moral values would be discarded by history and others added to the moral code. Judah's aunt does not advocate immoral behaviour, but draws attention to the small value of taking a high moral position, if this position is not accompanied by a decent 'life position' or even life itself. In other words, the aunt warns against adulating moral values at the expense of other values. She even suggests that in longer run moral values might suffer if they are edified too much.

Cliff's plot can also be treated as a moral tale in its own right and as a commentary to Judah's story. Cliff lives with the conviction that he occupies the high moral ground and certainly that he is more moral and intellectually superior to Lester. This is because his brother-in-law's domain is entertainment without any moralistic or intellectual pretensions, while Cliff's films do try to instil in the viewers high moral values. Cliff's main project is a documentary about a Jewish moralist and scientist and a Holocaust survivor, Professor Louis Levy. Cliff collected plenty of material about Levy, but for financial and psychological reasons cannot finish his project. Levy appears to be the main moral authority for Cliff. This is because of his ascetic style, which Cliff describes as 'no limos, no bimbos', and his general outlook on life. On the basis of the fragments of interviews included in the footage, we can derive that Levy's philosophy consists of two elements. One is atheism. Levy talks about God as invented by people and claims that people were unable to invent him as a good, benevolent entity. The second part of Levy's personal philosophy appears to be his affirmation of life based on some kind of psychoanalytical concept of human existence as an imaginary return to a happy childhood. However, during the narrative we learn that Levy committed suicide, thus undermining his affirmative stance, and damaging the foundations of Cliff's faith, as well as diminishing his chance of ever finishing the film.

Louis Levy is a fictitious character, but his surname, views and the way he ends his life link him with the writer and Holocaust survivor, Primo Levi. Levi's views, included in his books, most importantly The Drowned and the Saved (see Levi 1988), have much in common with those of Williams. Through his description of the moral aspect of living in a concentration camp Levi offers a convincing debunking of the faults of Kantianism. He draws attention to the relationship between moral and other values and luck and morality, especially the difficulty to behave decently when one is deprived of basic necessities and has to fight for survival.

Cliff's inability to achieve what society regards as success and his failure to achieve a victory even on his own terms, namely finishing his film about Levy and marrying Halley, undermine his moral credentials. The fiasco of the Levy documentary exposes its author as somebody who in reality has little to offer society, is all words and no action. As his story progresses we discover in him a parasite who most likely lives off his rich family and an escapist who seeks in old films a shelter from troubling reality. Visually, this idea is conveyed by showing Cliff locked in his dark studio, amid reels of footage about Louis Levy and most likely other films that he was unable to finish. Even if we agree that Cliff represents a higher moral standard than his shallow brother-in-law, then we must also accept that this high morality is represented by Allen as paralysing and alienating its bearer from the world, as it creates a gap between the high minded individual and the rest of the world.

Halley's rejection of Cliff lies in the fact that she is essentially a good person: modest, honest and appearing immune to the world's shallow temptations. The moral significance of Cliff's expectation that she will marry him thus comes across as rational. Although Halley does not spell out why she rejects Cliff and chooses Lester, one guesses that she is put off by Cliff's ineffectiveness and warms to Lester seeing his success and charm, while failing to notice his faults such as his flirtatiousness and selfishness. ${ }^{(4)}$ Off-screen Allen confirms the aforementioned interpretation of Halley's choice by saying: 'It isn't enough to have a good heart and to aim high. Society pays off on success. The fact that Lester is a fool does not matter. He's successful. And because he's successful, they want him at universities to lecture, they want to give him awards. And 
a woman like Halley winds up liking him. Then, when it comes to Cliff, it's irrelevant to people that your intentions are good. In real life, when I finish a movie, I can pound on people's chests and say, "But look, my intentions were so good!" They don't care. They pay off on winners. And winners mean fame, money, material success' (Björkman 2004: 219).

It is difficult to find an opinion more anti-Kantian in the sense of dismissing good intentions and attaching so little value to moral values. By slighting his own character, Allen goes much further than Williams who does not show disrespect for moral intentions and moral values, only acknowledges that both moral intentions and consequences matter, and that moral values do not always have primacy over other values. Off-screen Allen goes further than on-screen, because within the diegesis he exhibits sympathy for his character and instils in the viewer a sense that life is unfair rewarding people like Lester and punishing those like Cliff.

As a man whose only claims to self-respect and a high position in society are his noble intentions, which prove meaningless even to decent people, Cliff's situation indirectly strengthens the position taken by Judah, who cares little about intentions and, for that matter, anything which remains hidden in (private) consciousness. Hence, the effect of the last scene of the film, in which Cliff shows surprise and horror when Judah confesses his crime to him, works as a way to validate Judah's act rather than proving him wrong.

Match Point contains a similar story to that of Judah and Dolores, but I will argue that the director's assessment of his characters' deeds is quite different. In this film a young tennis instructor named Chris, married to Chloe, daughter of a rich industrialist, has an affair with Nola, a beautiful, aspiring actress who used to be the girlfriend of his brother-in-law, Tom. Chris fell in love with Nola even before he married Chloe, but he kept his interest in her secret, convinced that he had no chance to snatch her from Chloe's brother. Chris makes Nola pregnant and she expects him to leave his wife (whom he claimed he did not love) and take care of her and their baby. He, however, does not want to do so because, like Judah, he cannot face his wife who loves him dearly and his parents-in-law who invested in him both financially and emotionally. More importantly, Chris knows that after getting a taste for luxury he will suffer if deprived of it, therefore is unwilling to give up the life of privilege granted to him by his marriage. Consequently, he decides to kill Nola and to make the murder look like a drug-related crime, also kills an elderly female neighbour and steals her jewellery. Although he becomes one of the suspects in the police investigation due to the police finding a diary in which Nola described their affair, and the chief investigator's belief that he was indeed the perpetrator, Chris avoids detection. The policeman's theory is undermined when a wedding ring Chris took from the neighbour's apartment and threw into the Thames is found in the pocket of a drug-addict caught in a burglary of a neighbouring building.

In common with Crimes and Misdemeanors, the story Allen tells in Match Point supports the main points of Williams' concept of 'moral luck'. Firstly, it draws attention to the fact that moral values have no supremacy over other values. Certainly Chris is represented as a man who, even before he decided to kill Nola, had little respect for moral values and was prepared to sacrifice them for material success and the friendship of influential people. His attitude is expressed at the beginning of the film when he says that the 'man who said "better to be lucky than good" saw deeply into life'. This sentence not only reveals Chris's belief that morality and happiness do not always go together and his preference for (good) luck over good character, but also his belief that this is or should be the case for everybody.

Secondly, Allen emphasises the importance of the consequences of human actions, rather than underlying intentions. On the one hand, it matters little that Chris does not really want to kill Nola and perhaps loves her even in the moment when he shoots her. What ultimately matters is that he kills her. On the other hand, in Chris' views, as in Judah's, his initially serious crime loses its gravity due to the fact that he avoids being caught by the police.

Thirdly, luck is depicted as a major factor in morality. In comparison with Crimes and Misdemeanors, this idea is developed even further by illuminating the significance of both constitutive luck and incident luck in the person's moral position. The Hewitt family, which Chris enters thanks to his marriage to Chloe, is depicted as people who can afford 'morally pleasing behaviour' because they are very rich. Their wealth allows them to sponsor arts and support charities, as well as be honest with each other and in their dealings with the outside world. By contrast, Chris, a poor Irishman trying to make a career in London, cannot afford any magnanimity, but must fight for himself, constantly violating basic moral rules. 
The role of incident luck is underscored by the recurrent motif of inanimate objects that once set in motion can move in different directions, causing a chain of events of grave significance. A tennis ball might hit the net and move backwards or forwards - depending on luck - making the person who hit it either the loser or winner of a game. We can imagine that if Chris, who was a tennis professional before he started coaching at an exclusive tennis club, had had better luck at tennis, he would not end up as a murderer. Similarly, a piece of stolen jewellery might end up in the river Thames or land on the pavement and be picked up by a drug addict who is then accused of murdering the owner of the jewellery. These are the most pointed examples of luck, used in the film, but all the time we are alerted to the fact that the protagonist will win or lose depending on minute occurrences, such as his wife finding something in his bag or accidentally overhearing a telephone conversation with his mistress.

Fourthly, the story presented in Match Point illustrates Williams' point that different people are at different distances from occurrences which have moral consequences. The difference in perspective on a moral act is perfectly illustrated in an imaginary scene when, after killing Nola and her neighbour, Chris talks to them explaining his position. It is clear that although in Chris's opinion he behaved rationally or even did the right thing in a moral sense, because he saved his marriage and Chloe and her family's happiness, he is unable to convince Nola or her elderly neighbour. For him their deaths are only 'collateral damage', as he puts it; for them it equals the loss of everything they possessed. It is impossible to harmonise their stances and Chris does not even try, knowing that such an attempt will be in vain.

The crimes Chris commits are similar to that of Judah and his 'moral measuring' is also no different from that of his cinematic predecessor. However, Allen presents Chris less sympathetically than the protagonist of Crimes and Misdemeanors. Firstly, at the time he decides to get rid of Dolores, Judah does not love her any more and perceives their whole affair as a one night stand that went on for too long, while it appears a distinct possibility that Chris would abandon Chloe in order to be with Nola because she is the love of his life. Her subsequent murder thus comes across as a greater surprise and as a more repulsive act than that of Judah. The 'collateral damage' is also on this occasion greater and more visible than the moral cost of Judah's crime, as it involves an elderly woman, Nola's unborn child and the drug addict wrongly accused of killing the women. Moreover, Judah cannot force himself to kill Dolores with his own hands; such an act frightens and disgusts him. One can conjecture that if there were no hired killers, Dolores' life might be saved. For Chris, on the other hand, killing his lover is not a problem. Judah also reveals what Bernard Williams in his 'Politics and moral character', describes as 'a habit of reluctance' The importance of this habit lies in the fact that 'only those who are reluctant or disinclined to do the morally disagreeable when it is really necessary have much chance of not doing it when it is not necessary (Williams 1981e: 62).

Judah is a reluctant sinner: neither of his decisions comes to him easily; on each step he thinks about the opposite act to that which he commits. We are made to believe that his habit of reluctance, his distaste of morally disagreeable acts might help to keep him away from repeating the same mistakes. Moreover, he suffers pangs of conscience and accepts that he cannot be forgiven either by Dolores or by God, if God exists. Some critics point to the possibility that Judah might never come to terms with his behaviour, that he might feel guilty all his life. By contrast, the protagonist of Match Point easily 'accepts the intolerable', therefore one can imagine that he will not shirk from committing a crime of similar gravity if he finds it convenient. Allen does not show him having any pangs of remorse.

The previously described imaginary scene when he is confronted by the 'ghosts' of Nola and her neighbour belong to the policeman's dream, not Chris'. Even when his son is born, he says that he hopes he will be lucky, suggesting that he does not mind if his child will follow his own, immoral path. The final difference between Judah and Chris, which makes the latter's crime more appalling, is that ultimately it does not liberate him, allowing him to lead a life which he finds natural, but confirms his imprisonment in a world in which he is a usurper, a pretend member, as fake as are his interests in opera or Dostoevsky.

While Judah is a less repulsive character than Chris, Nola is more attractive than Dolores. Played by Scarlett Johansson, regarded as one of the most attractive American actresses of her generation, she is young, physically alluring, witty and flamboyant. Unlike Dolores, who appears lacking the style of Judah's upper-class wife, Nola, despite her modest background, easily outshines Emily Mortimer's plain, clumsy and devoid of good taste Chloe. One reviewer even noted that when Johansson, who brings to her part a 'mix of 
playful allure, piercing vulnerability and bolshie resolve' and is the film's 'most compelling, vivid presence' (Lawrenson 2006: 64) disappears from the screen, the film loses its 'sparkle', precisely because all remaining characters are dull and unappealing.

It is also worth noting that, unlike in Crimes and Misdemeanors, in Match Point there is no equivalent of Cliff, a character whose naïve 'morality' partially validates Judah's immorality. On the contrary, secondary characters undermine the path Chris chose. For example, Chris' old friend who remained a tennis professional, embodies not only adherence to a simple moral code, but represents the positive values such as self-reliance and freedom, which Chris lost by marrying into the Hewitt clan.

\section{'Whatever works'}

I would like to finish my discussion of Allen's morality by referring briefly to Allen's later film Whatever Works (2009). While in the two Allen films previously discussed the position of the film's author had to be reconstructed from the fates of the main characters, in Whatever Works this position is presented in an almost explicit way, through the utterances of the main character and Allen's mouthpiece, Boris Yellnikoff. He keeps saying several times in the film that 'whatever works' in life should be followed and accepted. His words are also repeated or paraphrased by other characters in the film who use this motto to rationalise their decisions. They include the divorced mother of the main protagonist who moves in with two men, her father who enters a gay relationship and her own daughter who first marries a man who could be her grandfather and then leaves him for a man her age. 'Whatever works' is also, albeit jokingly, mentioned as an apology for a sexual liaison between a man and a sheep. Allen's point is that all these decisions work for these characters because in the end everybody finds what s/he is looking for.

The focus on luck, coincidence, the extensive use of bizarre sequences of events links Whatever Works with the two films I discussed so far. Yet, in Crimes and Misdemeanors and Match Point the director, by repeatedly drawing attention to the situations which do not work for some individuals concerned and hence to the conflict of values, suggested that moral actions should be considered in a wider social framework. In Whatever Works, on the other hand, moral activities are reduced to unreflective pursuit of (largely sexual) pleasure. Equally, a wider framework is purposefully obfuscated or ridiculed, by associating the idea of moral life with the philistine and hypocritical Christian America. The moral choice offered in this film is thus between, on the one hand, utter hedonism which the protagonist and author appears to endorse whole-heartedly ${ }^{(5)}$ and, on the other, the rigid rules of conservative Christianity. By foreclosing wider moral discussions, Allen in a sense mimics the bulk of Western politicians at the time his film was made, who typically reduced political decisions to choosing between 'whatever works' and what would not work, because it is based on some archaic, arbitrary and irrational moral rules. This choice strikes me as too narrow, obscuring the wider selection of moral positions available. The concept of moral luck, which Allen himself, consciously or not, deployed in some of his films, helps to see clearly the complexity of the moral fabric of human life and hence attests to the potentiality of film to deal with moral issues in a sophisticated way.

\section{Notes}

1. He revealed his distrust of a moral theory by writing 'There cannot be any very interesting, tidy or self-contained theory of what morality is, nor, despite the vigorous activities of some practitioners, can there be an ethical theory, in the sense of a philosophical structure which, together with some degree of empirical fact, will yield decision procedure for moral reasoning' (Williams 1981d: ix-x). In his anti-theory stance Williams come close to Rorty (see Rorty 1989).

2. Although he analyses the ways moral philosophy tackled these questions (see Williams 1985a).

3. This in itself is an illustration of Williams' point that in real life moral values often compete and lose with other values, such as aesthetic ones, such as his case of 'Gauguin'.

4. In her naïve adulation of Lester Mia Farrow both recounts her past experiences with charming, but philandering husbands, and forebodes her future experiences with Allen who also proved unfaithful.

5. The position taken by Allen in this film might be captured by the term 'pragmatic optimist', used by Ian Jarvie in his discussion of earlier Allen's films. However, the way Jarvie supports his claim strikes me 


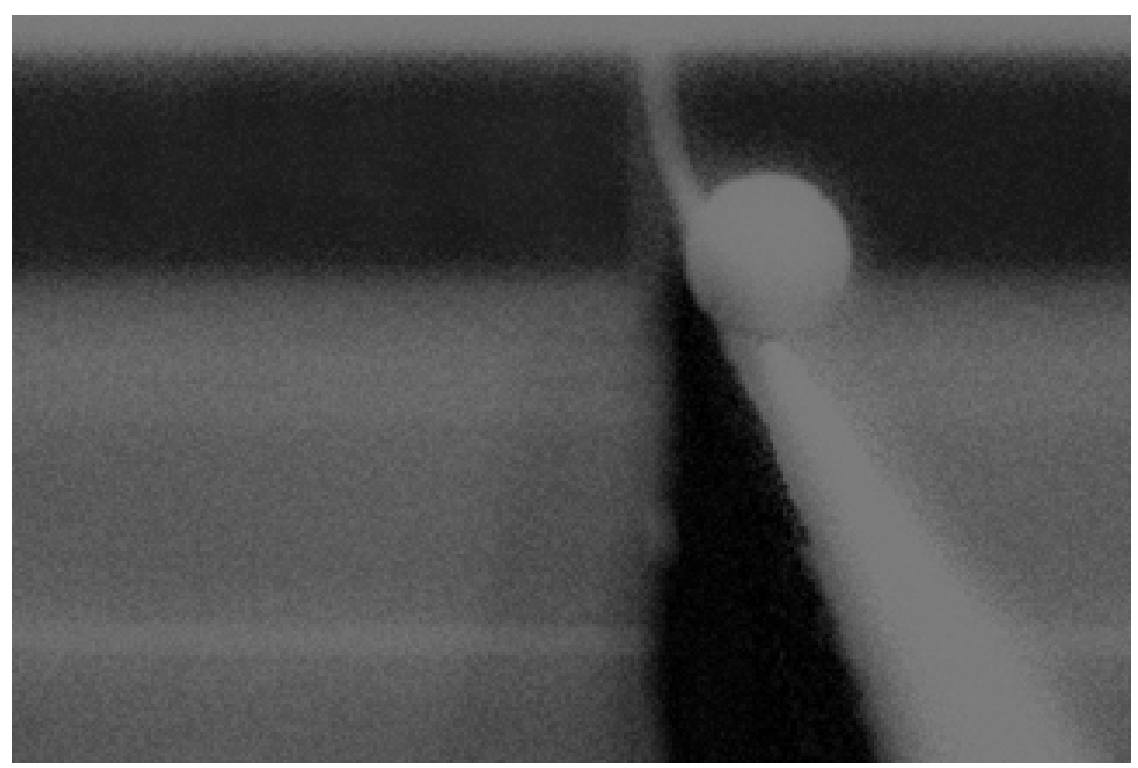

Figure 1:

as weak: "Pragmatic" because to go on making thoughtful films is to affirm optimism by action" (Jarvie 2004: 48). According to this definition, a large proportion of filmmakers are pragmatic optimists, even those known for making pessimistic films, such as Bresson, Bergman or Antonioni.

\section{References}

Allen, Richard (1990). 'Crimes and Misdemeanors', Cineaste, 4, pp. 44-6.

Björkman, Stig (2004). Woody Allen on Woody Allen, rev. edition (London: Faber and Faber).

Combs, Richard (1990). 'Woody's Wars: Crimes and Misdemeanors', Sight and Sound, 3, pp. 207-8.

Fründt, Bodo (1990). 'Die Augen wollen sich nicht zu jeder Zeit schließen', Süddeutsche Zeitung, 3, p. 8.

Geist, Kenneth (1989). 'Crimes and Misdemeanors', Films in Review, December, pp. 589-91.

Jarvie, Ian (2004). 'Arguing Interpretation: The Pragmatic Optimism of Woody Allen' in Mark T. Conard and Aeon J. Skoble (eds) Woody Allen and Philosophy (Chicago: Open Court), pp. 48-65.

Girgus, Sam B. (2002). The Films of Woody Allen (Cambridge: Cambridge University Press).

Kant, Immanuel (1993). Critique of Practical Reason (Mineola, New York: Dover).

Lawler, James (2004). 'Does Morality Have to Be Blind: A Kantian Analysis of Crimes and Misdemeanors' in Mark T. Conard and Aeon J. Skoble (eds) Woody Allen and Philosophy (Chicago: Open Court), pp. 33-47. Lawrenson, Edward (2006). 'Match Point', Sight and Sound, 1, pp. 63-4.

Levi, Primo (1988). The Drowned and the Saved, trans. from Italian by Raymond Rosenthal (London: Michael Joseph).

Nussbaum, Martha C. (2003). 'Tragedy and Justice: Bernard Williams remembered', Boston Review, http://bostonreview.net/BR28.5/nussbaum.html.

Pappas, John (2004). 'It's All Darkness: Plato, The Ring of Gyges, and Crimes and Misdemeanors' in Mark T. Conard and Aeon J. Skoble (eds) Woody Allen and Philosophy (Chicago: Open Court), pp. 203-17.

Rorty, Richard (1989) Contingency, Irony and Solidarity (Cambridge: Cambridge University Press). 
Strick, Philip (1990). 'Crimes and Misdemeanors', Monthly Film Bulletin, 8, 220-2.

Williams, Bernard (1981a). 'Moral luck' in his Moral Luck: Philosophical Papers 1973-1980(Cambridge: Cambridge University Press), pp. 20-39.

, Bernard (1981b). 'Utilitarianism and moral self-indulgence' in his Moral Luck: Philosophical

Papers 1973-1980 (Cambridge: Cambridge University Press), pp. 40-53.

, Bernard (1981c). 'Persons, character and morality' in his Moral Luck: Philosophical Papers 19731980 (Cambridge: Cambridge University Press), pp. 1-19.

Bernard (1981d). 'Preface' to his Moral Luck: Philosophical Papers 1973-1980 (Cambridge: Cambridge University Press), pp. ix-x.

, Bernard (1981e). 'Politics and moral character' in his Moral Luck: Philosophical Papers 1973-1980 (Cambridge: Cambridge University Press), pp. 54-70.

pp. 1-21.

, Bernard (1985a). 'Socrates' Question' in his Ethics and the Limits of Philosophy (London: Fontana),

, Bernard (1985b). 'The Archimedean Point' in his Ethics and the Limits of Philosophy (London:

Fontana), pp. 22-9.

\section{Author Information}

Ewa MAZIERSKA is Professor of Contemporary Cinema at the Department of Humanities, University of Central Lancashire. Her publications include Masculinity in Polish, Czech and Slovak Cinema, Roman Polanski: The Cinema of a Cultural Traveller, Women in Polish Books (with Elżbieta Ostrowska), Crossing New Europe: The European Road Movie (with Laura Rascaroli), Dreams and Diaries: The Cinema of Nanni Moretti, and From Moscow to Madrid: Postmodern Cities, European Cinema. She also co-edited Relocating Britishness. 